\title{
Senior Editors' Note
}

Issue 79 of International Labor and Working Class History focuses on labor migration into and within the Middle East. A geographically dispersed region encompassing nations in Asia, Africa, and Europe, the Middle East has functioned since ancient times as a crossroads for conquerors, merchants, workers, and ideas linking these three continents. These confluences persist today, with the region reliant on a vast transnational migrant workforce drawn from these three continents. The region's emergence as the core of the world's energy economy has led it to become so reliant on foreign workers that in some states they constitute the majority of the labor force. Denied the protections of citizenship, these workers have been subject to exploitative labor practices-including contract labor, debt peonage, and corrupt pay systems - and have been forced to live in unhealthy and unsanitary conditions. For national governments, this creates a troubling contradiction: While they are forced to rely on migrant labor, they are ill-prepared to deal with the sociopolitical conflict created by a diverse and uprooted population. A sustained and troubling period of political crises has similarly created one of the largest refugee populations in the world. Among them are not only the poor or dispossessed but a transnational community of dissident activists, professionals, intellectuals, and military personnel. Together, they have helped to shape workers' struggles and political movements in many states. The articles in this issue follow the geographical contours of the source and recipient areas of migrants: the countries of South Asia, the Eastern Mediterranean, the Persian Gulf, and the Arabian Peninsula.

$I L W C H$ is fortunate to have, as issue editors, two of our board members, whose own specializations follow the geographical sweep of this migration. Prasannan Parthasarathi (Boston College) is an economic and labor historian of the British Empire and South Asia, a region inextricably linked to the Middle East through the pathway of the Indian Ocean. Donald Quataert (Binghamton University) is a historian of Middle Eastern and Ottoman social and labor history. The collapse of the Ottoman Empire after the First World War facilitated a further entrenchment of Western imperialism, yet also opened the door to a variety of Pan-Arab nationalist movements that reflected both radical and moderate political tendencies. Following the Second World War, migrant politics emerged from these earlier struggles and featured the prominent influence of exiled intellectuals, activists, communists, and trade unionists who circulated throughout the region. They shaped debates about the nature of political reform, Arab unity, liberal democracy, and antimonarchism and gave form to the generalized critique of conditions of work and society that emerged among workers employed in foreign and local industries, particularly in the oil fields. Despite the depoliticized trade union policies of imperial 
powers and local elites, these foreign and local workers led struggles that extended beyond economistic demands, much to the dismay of the British, and delved into the political realm by challenging authoritarian governments.

Parthasarathi and Quataert have brought together a stimulating series of articles that make new, insightful, and, in some cases, provocative contributions to our understanding of the vulnerabilities and power of migrant workers and the ways that they shape and are shaped by the current politics of the region and beyond. Several articles challenge conventional assumptions about the destructive role migrant labor allegedly plays in diverting and weakening the struggles of local labor, arguments that have important implications for many other regions of the globe. On the contrary, the case studies find that migrants have been transmitters of reformist and even revolutionary ideas, novel forms of worker association and industrial strategies, and popular-based critiques of undemocratic governments. Many migrants, in fact, were instigators of local workers' struggles.

Several of the articles extend beyond the region to nations in South Asia that have sent hundreds of thousands of workers to the Middle East over the centuries. They describe the impact of the cycles of migration on local politics and economy in source areas of migration and suggest new ways that these migrants insert themselves into home politics. One article details an extraordinary exercise of migrants' political power that forced a shift in the foreign policy of their home country, the Philippines. An association of Filipino migrants pressured their government to comply with kidnappers' demand that it withdraw troops from Iraq as a precondition for the release of an abducted Filipino worker. The government yielded to pressure, agreed to withdraw its troops, and the worker was released safely. This case suggests that migrants, in their position as a significant contributor to national income, can create new vehicles for the expression of political power in a transnational setting.

Many of these articles discuss how workers expose and exploit points of vulnerability in host countries. This was especially the case in the immediate postwar period, when Pan-Arab nationalism and the influence of Nasser's revolution ignited an excitement among exiles and migrants about the possibilities of liberal democracy in the region. As governments struggled to prevent their dependence on migrant labor from reshaping their national identity, they confronted dissident movements that flared up intermittently to challenge monarchial rule. The complexity of these struggles_among labor, capital, and the state-make this section of the issue a valuable resource for understanding the current realities in the Middle East, as well as its recent past.

This issue contains two other contributions. One, which complements the thematic section, is about contract workers from the tribal areas of central India and their memory of industrial struggles during two phases of India's development: the period of state ownership of key industries in the 1970s and the period of neoliberalism in the 1990s, when government facilitated foreign and private capital. Manjusha Nair argues that workers' accounts of strikes in state-owned iron ore mines in the 1970s and in privately owned industries in 
the 1990s differed substantially in their expectations of protection by the state, assumptions of rights as citizens, and faith in collective bargaining as a legitimate mechanism for workers' rights. The narratives of those who worked in the state industry exhibited assertiveness, pride, and solidarity when they recalled their successes against the state, which they felt was responsible for their welfare. In contrast, workers in privatized industries during the age of neoliberalism recalled their struggles in a discourse of passivity, victimization, disempowerment, and personal humiliation. These experiences of alienation, Nair argues, help to explain why the Maoist movement is enjoying a resurgence in central India.

The second piece is a review essay that surveys several texts on the early colonial encounter in Latin America, Africa, Canada, and Australia. Robert Nelson notes the absence of people in the accounts of early European pioneers visiting these territories. He argues that the conscious erasure of indigenous people from the landscape of areas being targeted for imperial conquest is not, as is usually assumed, because of racism but, rather, because of contempt for the ways that these communities used the land, defined property, and performed labor. The failure to practice agriculture rather than pastoralism, to be settled rather than nomadic, were, to these observers, key indicators of how these peoples should be treated as colonial subjects. It is a provocative essay that introduces a different lens to view the violence of the "colonial encounter."

Our plans for future issues are equally exciting. Issue 80 for fall 2011 focuses on labor and the military and will be edited by Joshua Freeman (CUNY Graduate Center) and Geoffrey Field (SUNY-Purchase). Mary Nolan (New York University) and Mae Ngai (Columbia University) are editing Issue 81, to appear in spring 2012, which will return to the issue of globalization but focus on labor in the production, circulation, and consumption of commodities. The issue will also reflect the contributions of the new scholarship in the burgeoning field of environmental history.

With this issue the journal brings on two new Senior Editors: Carolyn Brown (Rutgers University), a labor historian of Africa, and Jennifer Klein (Yale University), a US labor historian, who will join Peter Winn (Tufts University). In turn, we would like to thank Dorothy Sue Cobble (Rutgers University) and Mary Nolan, who now rotate off as Senior Editors of $I L W C H$. They were both instrumental in negotiating the journal's move to Rutgers and the renewal of our contract with Cambridge University Press. As a member of the faculty of History and School of Labor and Management Studies, Cobble secured support from both Rutgers bodies for the journal. We wish to give our resounding appreciation to both Rutgers entities for the support and encouragement they have given the journal. We also want to thank Allison Miller, our talented managing editor, for her professionalism, knowledge, skill, and commitment in nursing the journal through the laborintensive production process. 